Vol 2 No 1 (2018) Page $111-117$

JURNAL OBSESI : JURNAL PENDIDIKAN ANAK USIA DINI

Research \& Learning in Early Childhood Education

https://obsesi.or.id/index.php/obsesi

\title{
Meningkatkan Kemampuan Kecerdasan Visual melalui Aplikasi Paint di RA Al Muhajirin Kota Cimahi
}

\author{
Tati Hayati ${ }^{1}$, Mimik Kurniawati ${ }^{2}$, Ramdhan Witarsa ${ }^{3 凶}$ \\ Program Studi PG-PAUD, FIP, IKIP Siliwangi Bandung
}

\begin{abstract}
Abstrak
Tujuan penelitian dalam artikel ini adalah untuk mengetahui bagaimana aktivitas anak usia dini dalam meningkatan kemampuan kecerdasan visual melalui aplikasi paint di RA Al Muhajirin Kota Cimahi dan untuk mengetahui berapa besar peningkatan kemampuan kecerdasan visual melalui aplikasi paint. Rumusan masalah dalam penelitian ini adalah Bagaimana aplikasi paint yang dilakukan terhadap kecerdasan visual anak usia dini di RA Al Muhajirin Kota Cimahi. Metode penelitian yang digunakan adalah metode Penelitian Tindakan Kelas. Subjek dalam penelitian ini adalah seluruh anak usia dini yang berjumlah 30 anak. Instrumen yang digunakan adalah pedoman observasi, wawancara, dan dokumentasi. Teknik analisis data menggunakan deskriptif kualitatif. Analisa data menggunakan tahap reduksi data, model data, dan penarikan kesimpulan. Hasil penelitian menunjukkan peningkatan pada kategori belum berkembang sebanyak 10 anak (30\%) menjadi 1 anak $(3,6 \%)$, pada kategori mulai berkembang sebanyak 14 anak (49,9\%) menjadi 5 anak (17,8\%), pada kategori berkembang sesuai harapan sebanyak 3 anak $(12,3 \%)$ menjadi 6 anak $(21,4 \%)$, dan pada kategori berkembang sangat baik sebanyak 3 anak $(9,7 \%)$ menjadi 16 anak $(57,2 \%)$. Dapat disimpulkan bahwa aplikasi paint dapat meningkatkan kemampuan kecerdasan visual pada anak usia dini di RA Al Muhajirin Kota Cimahi.
\end{abstract}

Kata Kunci: kecerdasan visual, aplikasi paint, anak usia dini.

\begin{abstract}
The purpose of research in this article is to find out how the activities of early childhood in improving the ability of visual intelligence through paint application in RA Al Muhajirin Kota Cimahi and to find out how much increase the ability of visual intelligence through paint applications. The research problem is how paint application done to visual intelligence of early child in RA Al Muhajirin Kota Cimahi. The research method used is Classroom Action Research method. Subjects in this study were all children early age of 30 children. The instruments used are observation guidelines, interviews, and documentation. Data analysis techniques used descriptive qualitative. Data analysis uses data reduction, data model, and conclusion. The results showed an increase in the underdeveloped category of 10 children $(30 \%)$ to 1 child $(3,6 \%)$, the category began to grow as many as 14 children $(49,9 \%)$ to 5 children $(17,8 \%)$, in the category developed as expected by 3 children (12,3\%) to 6 children $(21,4 \%)$, and in very good developing category as many as 3 children $(9,7 \%)$ to 16 children $(57,2 \%)$. It can be concluded that paint application can improve the ability of visual intelligence at early childhood in RA Al Muhajirin Kota Cimahi.
\end{abstract}

Keywords: visual intelligence, paint application, early childhood.

@Jurnal Obsesi Prodi PG-PAUD FIP UPTT 2018

$\triangle$ Corresponding author : Ramdhan Witarsa

Address : FIP IKIP Siliwangi, Jalan Terusan Jenderal Sudirman

Email : ramdhanwitarsa@ikipsiliwangi.ac.id

ISSN 2356-1327 (Media Cetak)

Phone : :081221568012

ISSN 2549-8959 (Media Online) 


\section{PENDAHULUAN}

Pemberian rangsangan pendidikan harus diberikan sedini mungkin, yaitu saat anak masih dalam usia emas atau biasa dinamakan "The Golden Age". Usia emas anak ketika ia berusia 0-6 tahun. (Indonesia, 2003) Usia dini merupakan bagian penting dalam kehidupan manusia. Anak usia dini merupakan anak yang berada pada rentang masa usia lahir sampai 6 tahun. (Ramli, 2005) Pada masa ini merupakan masa yang paling efektif untuk pengembangan potensi dalam mengembangkan aspek perkembangannya, yang meliputi pengembangan pembiasaan (moral dan nilainilai agama, sosial, emosional, dan kemandirian), bahasa, kognitif, motorik dan seni (Joni, 2015).

Orang tua dan pendidikan harus pandai memberi rangsangan berupa pendidikan yang disesuaikan dengan potensi yang dimiliki oleh anak. Pada dasarnya setiap anak dikaruniai potensi kreatif sejak lahir. Hal ini dapat dilihat dari perilaku anak dalam mengeksplorasi apapun yang ada disekitarnya secara alamiah. Pendidikan pada masa usia dini merupakan wahana pendidikan yang fundamental dalam memberikan kerangka dasar yang dibentuk dan dikembangkan atas dasar-dasar pengetahuan, sikap, dan keterampilan pada anak.

Keberhasilan proses pendidikan pada masa usia dini tersebut memiliki dampak terhadap pengembangan kemampuan untuk berbuat dan belajar pada masa-masa berikutnya. Proses pembelajaran pada masa usia dini hendaknya dilakukan dengan tujuan memberikan konsep yang bermakna bagi anak melalui pengalaman nyata, sebab dengan pengalaman nyata memungkinkan anak berkembang secara opimal. (Sujiono, Nurani, \& Yuliani, 2009)

Proses pembelajaran yang dapat mengembangkan hal tersebut salahsatunya melalui pembelajaran yang mengoptimalkan media komputer. Kecerdasan anak dapat dimaksimalkan dengan memiliki keterampilan dalam menguasai penggunaan aplikasi komputer paint. Lina (2016) dan Musfiroh (2005) berpendapat bahwa anak yang cerdas adalah anak yang memiliki kecerdasan dalam visual, dimana mereka memiliki kepekaan terhadap warna, garis-garis, bentuk, ruang, dan bangunan, serta memiliki kemampuan membayangkan sesuatu dan melahirkan ide secara visual (dalam bentuk gambar).

Hal ini berarti anak yang memiliki kecerdasan visual suka akan kegiatan mencoretcoret, membentuk gambar, mewarnai, dan menyusun bangunan seperti puzzle dan balok. Anak yang memiliki potensi kecerdasan visual yang tinggi akan mampu berpikir dalam bentuk gambaran dan mampu menemukan objek yang hilang dalam kaitan dengan kemampuan dibidang daya ingat visual. Anak dengan kecerdasan visual yang tinggi diharapkan kelak bisa memiliki profesi sebagai seorang pelukis, arsitek, fotografer, desainer, seniman, pilot, nahkoda, dan para penemu teknologi.

Berdasarkan hasil observasi di RA Al Muhajirin Kota Cimahi pada bulan Juli 2017, terlihat adanya permasalahan pada kemampuan visual anak. Hal ini terlihat dari rendahnya kemampuan anak dalam kegiatan yang melibatkan visual seperti menggambar, melukis, mencoret-coret, dan membuat prakarya. Peneliti mencoba meningkatkan kemampuan visual melalui aplikasi paint komputer di TK Al Muhajirin Kota Cimahi. Aplikasi paint pada komputer dipilih untuk kecerdasan visual ini peneliti lakukan untuk dapat mengembangkan kemampuan anak dalam menggambar menggunakan aplikasi paint dan menambah minat belajar anak agar anak mengenal bahwa menggambar tidak hanya dilakukan pada buku gambar saja, namun dapat dilakukan dengan aplikasi paint pada komputer. Melihat perkembangan zaman saat ini, anak lebih cepat mengenal dan mampu mengoperasikan dengan baik ketika proses pengenalan aplikasi paint ini dilakukan. Minat belajar anak juga sangat bertambah, sehingga setiap anak selalu bertanya "Kapan bu masuk komputer, hari ini kita gambar apa?"“. Aplikasi paint untuk kecerdasan visual anak ini diharapkan mampu membuat minat belajar anak bertambah dan mereka bersemangat untuk ke sekolah. Kondisi ini dapat dimanfaatkan untuk mengembangkan kemampuan visual anak dengan mengenal gambar, bentuk, warna dan lain-lain.

Pada umumnya, kemampuan kecerdasan visual anak masih rendah, ini dibuktikan dengan hasil penelitian Lina (2016) yang menunjukkan hasil perhitungan dari uji statistik Anova diperoleh nilai $\mathrm{R}$ square $=0,620$, dan 0,622 , yang berarti keterampilan berpengaruh terhadap kecerdasan visual spasial sebesar $62,2 \%$ dan keterampilan berpengaruh terhadap kecerdasan kinestetik sebesar $62 \%$.

Keterlaksanaaan penelitian, awalnya pendidik terlihat agak canggung dengan metode yang akan dilakukan, setelah dilakukan pengarahan teknis pelaksanaannya dan pengenalan intrumen yang akan digunakan, untuk tahap pertama masih ada 
kendala dalam urutan kegiatan sehingga peneliti sering terlibat langsung bersama pendidik.

Pada pelaksanaan tahap 2, pendidik sudah mulai mandiri untuk melaksanakan kegiatan. Untuk meningkatkan kecerdasan visual anak, menurut Musfiroh (2005) guru dapat merangsang melalui program seperti melukis, menggambar, membentuk sesuatu dengan plastisin. Guru juga perlu menyediakan berbagai fasilitas untuk mengembangkan daya imajinasi anak dan juga menyediakan beberapa miniatur benda seperti pesawat, hewan, orangorangan, dan lain sebagainya. Jadi dengan kata lain, kegiatan pembelajaran yang dipilih hendaknya kegiatan yang menyenangkan, dapat menggerakkan anak untuk meningkatkan motivasi, rasa ingin tahu, dan mengembangkan imajinasinya serta mampu mendorong anak mencari dan menentukan jawaban yang membantu memecahkan, memikirkan kembali, membangun kembali, dan menemukan hubungan-hubungan baru atau dengan kata lain mampu menerapkan apa yang mereka pelajari ke dalam kehidupan mereka.

Kecerdasan visual merupakan salah satu bagian dari kecerdasan jamak yang berhubungan erat dengan kemampuan untuk memvisualisasikan gambar di dalam pikiran seseorang atau untuk anak dimana dia berpikir dalam bentuk visualisasi dan gambar untuk memecahkan sesuatu masalah atau menemukan jawaban (Lina, 2016).

Kecerdasan majemuk merupakan keanekaragaman kemampuan yang menyangkut beberapa bidang. Materi program dalam kurikulum yang dapat mengembangkan kecerdasan visual antara lain: video, gambar, dan model atau diagram. Kecerdasan visual, yaitu merupakan kecerdasan yang dikaitkan dengan bakat seni lukis dan arsitektur. Untuk itu, para pendidik harus memberikan ruang gerak yang memadai bagi anak untuk mengembangkan kecerdasan visual. Kecerdasan visual harus dirangsang dengan baik. Jika tidak, maka kecerdasan visual tidak akan berkembang dengan optimal (Pebriana, 2017).

Pada anak juga terdapat kecerdasan finansial. Anak dengan kecerdasan finansial ataupun pemahaman finansial baik akan memiliki pilihan yang optimal seperti halnya memilih lebih banyak menabung, menyesuaikannya dengan uang dimiliki, serta mempunyai pertimbangan prioritas untuk membeli sesuatu keperluan / keinginannya. (Nik Amah, 2017)
Dengan demikian, anak memiliki kesempatan untuk muncul dan berkembang mencapai tahap yang semakin optimal, sehingga setiap anak berkesempatan menunjukkan kecenderungan, kepekaan, dan kemampuan dari kecerdasan yang dimilikinya. Kecerdasan visual dapat dirangsang dengan melalui berbagai program seperti melukis, mengambar menggunakan aplikasi paint pada komputer, membentuk sesuatu dengan plastisin, mengecap, dan menyusun potongan kertas menjadi bentuk gambar (kolase).

Kegiatan dalam pengembangan kecerdasan visual dapat dilakukan dengan pembelajaran kreatif. Pembelajaran kreatif sangat baik jika dilakukan dengan cara bermain. Seperti prinsip pembelajaran di RA, yaitu "Belajar melalui bermain". Pembelajaran seperti ini akan sangat menyenangkan bagi anak, sehingga anak tidak akan bosan dan jenuh. Anak dapat bereksperimen dengan gagasan-gagasan barunya baik dengan menggunakan alat bermain maupun tidak. Sekali anak merasa mampu menciptakan sesuatu yang baru dan unik ia akan melakukannya kembali dalam situasi lain. Bermain adalah awal timbulnya kecerdasan visual karena dalam kegiatan yang menyenangkan, anak akan dapat mengungkapkan gagasan-gagasannya secara bebas dalam hubungan dengan lingkungannya. Oleh karena itu, kegiatan tersebut dapat dijadikan sebagai salah satu dasar dalam mengembangkan kecerdasan visual anak.

Kecerdasan visual pada dasarnya dimiliki setiap manusia, hanya saja dalam perjalanan hidupnya ada yang mendapatkan kesempatan untuk mengembangkan potensi kecerdasannya, ada pula yang kehilangan potensi kecerdasannya karena tidak mendapatkan kesempatan ataupun tidak menemukan potensi kecerdasannya di lingkungan yang memfasilitasi berkembangnya potensi tersebut.

Aplikasi paint pada komputer adalah salah satu program (software) pengolah gambar, aplikasi paint merupakan salah satu aplikasi bawaan dari microsoft windows. Jadi program windows selalu ada aplikasi pengolah gambar yaitu paint. Setiap windows tampilan aplikasi paintnya berbeda, tetapi pada prinsipnya cara penggunaannya sama. Langkah-langkah menjalankan aplikasi paint sebagai berikut: 1. Buka aplikasi microsoft paint dengan klik tombol start yang ada di taskbar; 2. Klik menu all program, accessories, paint; 3 . Jendela paint akan ditampilkan. 


\section{METODE}

Penelitian ini menggunakan metode penelitian tindakan kelas. Penelitian tindakan kelas merupakan upaya untuk meningkatkan kinerja sistem organisasi atau masyarakat agar lebih efektif dan efisien (Mulyasa, 2009). Tahapan yang digunakan dalam penelitian ini adalah melakukan identifikasi persoalan, menentukan data, mengumpulkan data dan analisa, merencanakan tindakan lanjutan, melaksanakan tindakan lanjutan dan kemudian evaluasi serta follow up.

Subjek penelitian adalah 30 orang anak yang terdiri dari 13 anak perempuan dan 17 anak laki-laki. Penelitian ini dilaksanakan di RA Al Muhajirin Kota Cimahi. Kegiatan ini dilakukan kurang lebih selama 3 bulan, dari awal Februari sampai akhir April 2017. Aktifitas dilakukan 2 kali pertemuan dalam satu minggu masing-masing kelas, setiap hari 3 tahap kelompok secara bergiliran masuk ke ruang komputer pada hari selasa dan jum'at. Kegiatan dimulai pukul 09.00-11.00 WIB.

\section{HASIL DAN PEMBAHASAN}

Perencanaan pembelajaran didasarkan pada hasil dokumentasi dan diperoleh data bahwa perencanaan pembelajaran di RA Al Muhajirin Kota Cimahi dilakukan dengan cara menyusun perencanaan program semester atau prosem, perencanaan kegiatan mingguan (RKM), dan perencanaan kegiatan harian (RKH). RKH dibuat berdasarkan RKM yang berbentuk webbing, dan RKM disusun berdasarkan prosem. Dalam satu hari dalam RKH, tidak semua kecerdasan dapat dikembangkan. Untuk penentuan tema, sekolah menyesuaikan kurikulum dari dinas.

Data wawancara tentang perencanaan pembelajaran diperkuat dengan adanya data dokumen sebagai berikut: Dokumen perencanaan pembelajaran yang terdiri dari dokumen program semester, dokumen RKM, dan dokumen RKH. Indikator yang ada pada RKH sesuai dengan indikator pada RKM pada mingguan tersebut, serta indikator pada RKM juga sesuai dengan pemetaan indikator pada program semester.

Perencanaan pembelajaran yang dilakukan berdasarkan data dokumen antara lain (1) perencanaan pembelajaran berupa prosem, RKM, dan RKH, (2) indikator pada $\mathrm{RKH}, \mathrm{RKM}$, serta prosem saling berkaitan (sinkron), karena RKH dibuat berdasarkan RKM sedangkan RKM disusun berdasarkan prosem, dan (3) pemilihan tema pada perencanaan pembelajaran berdasarkan tema dari dinas.

Pelaksanaan pembelajaran berdasarkan hasil observasi, dan dokumentasi sebanyak 2 kali pertemuan dalam 1 minggu yang dilaksanakan selama 1 bulan, diperoleh data bahwa pelaksanaan pembelajaran terdiri dari kegiatan ATP (At The Playground), kegiatan awal, kegiatan inti, istirahat, serta kegiatan akhir.

Deskripsi hasil penelitian pada tahap tindakan terlebih dahulu disediakan bahan dan alat yang dapat digunakan sebagai media dalam menggunakan aplikasi paint yang dapat di perlihatkan di RA Al Muhajirin Kota Cimahi, kemudian dilakukan pengamatan awal dengan menggunakan tabel observasi tentang hasil belajar melalui penggunaan aplikasi paint pada peningkatan kemampuan visual, yang muncul pada pengembangan fisik motorik dan seni seorang anak.

Selanjutnya, dibuatlah skenario pembelajaran yang dilakukan pada pembelajaran di RA Al Muhajirin, yaitu berupa RKH. Skenario pembelajaran yang sesuai dengan tema-tema dan kompetensi dasar dari bidang pengembangan aspek seni, indikator dengan menggunakan komponen-komponen penggunaan media yang lebih efektif dan efisien. Setelah menyusun skenario pembelajaran, peneliti juga menyusun lembar observasi.

Lembar observasi ini dimaksudkan sebagai alat untuk mengamati kondisi pembelajaran. Pengembangan aspek seni di kelompok belajarnya pada saat anak melaksanakan kegiatan menggambar menggunakan aplikasi paint.

Kegiatan lain yang dilakukan dalam tahap persiapan adalah merancang alat evaluasi yang digunakan untuk mengukur peningkatan hasil belajar anak dalam penggunaan teknik menggambar menggunakan aplikasi paint yang benar. Alat evaluasinya berupa non tes. Penilaian non tes ini dilakukan dengan mengamati kegiatan anak selama berlangsung pembelajaran dan diisi pada lembar observasi hasil siklus I. Pelaksanaan tindakan merupakan tahap yang dilakukan terhadap rancangan yang telah disusun sebelumnya berdasarkan masalah yang dihadapi. Dalam tahap ini, guru melaksanakan pembelajaran sesuai dengan skenario yang telah disiapkan sebelumnya. Berdasarkan skenario yang telah dibuat, guru melaksanakan tindakan didalam kelompok belajarnya. Tindakan I yang dilaksanakan adalah dengan menerapkan pembelajaran 
pengembangan aspek visual melalui penggunaan aplikasi paint dengan teknik menggambar dengan benar.

Berdasarkan tindakan yang diberikan kepada anak pada tindakan I, selanjutnya diolah dan dianalisis secara bersama-sama. Analisis data dilakukan untuk memudahkan dalam merefleksi pembelajaran agar dapat menyusun rencana pemecahan masalah pada langkah pembelajaran selanjutnya. Observasi dilakukan dalam pelaksanaan tindakan dengan menggunakan lembar pengamatan yang telah disiapkan. Pengamatan pertama sekali dilakukan terhadap pelaksanaan tindakan I. Observasi ini dilakukan bertujuan untuk melakukan proses pembelajaran pengembangan aspek visual melalui penggunaan aplikasi paint teknik menggambar untuk melatih kemampuan motorik halus anak secara langsung dikelompok belajarnya.

Berdasarkan hasil pengamatan tindakan I, dilakukan analisis dan direfleksikan sehingga diperoleh gambaran untuk perencanaan selanjutnya. Observasi selanjutnya dilakukan terhadap peningkatan hasil belajar pengembangan aspek visual melalui penggunaan teknik menggambar menggunakan aplikasi paint dalam upaya melatih kemampuan visual anak di RA Al Muhajirin Kota Cimahi.

Hasil pengamatan yang diperoleh selanjutnya dianalisis dan direfleksi. Hasil pengamatan dianalisis pada masing-masing tindakan. Refleksi tindakan I dijadikan dasar penentuan langkah alternatif pemecahan masalah.

Selanjutnya, hasil refleksi dari tindakan dijadikan sebagai dasar penyimpulan terhadap proses pembelajaran pengembangan aspek visual melalui penggunaan teknik menggambar menggunakan aplikasi paint untuk melatih kemampuan kecerdasan visual anak.

Untuk memperoleh deskripsi yang objektif terhadap pelaksanaan tindakan dalam penelitian ini, peneliti menggunakan lembar pengamatan. Lembar pengamatan menyangkut dengan aspek-aspek yang dinilai, yaitu aspek kognitif, aspek afektif, dan aspek psikomotorik. Aspek kognitif yang diamati terdiri atas kemampuan anak menyerap informasi tentang pengetahuan pengembangan aspek visual dari penjelasan guru. Selanjutnya aspek afektif menyangkut dengan keaktifan anak mengikuti pembelajaran dengan melatih kemampuan motorik halus anak melalui aplikasi paint. Pelaksaan tindakan siklus I didasarkan pada hasil evaluasi dan refleksi hasil observasi awal. Selanjutnya, peneliti mendasarkan pada rencana pelaksanaan tindakan yang mengacu kepada hasil evaluasi dan refleksi tindakan I.

Berdasarkan siklus yang dilalui pada pembelajaran pengembangan aspek visual melalui aplikasi paint untuk melatih kemampuan visual anak, disusunlah simpulan penelitian.

Proses pembelajaran sebelum dilakukan tindakan dan sesudah dilaksanakan tindakan dengan menggunakan aplikasi paint sebagai alat bantu terjadi peningkatan. Tergambar dari tingginya minat belajar anak dalam mengikuti pelajaran dengan teknik menggambar menggunakan aplikasi paint dengan bentuk gambar dan hasil warna gambar membuat anak bertanya kenapa bisa gambar tersebut berwarna dari masing-masing gambar dan kombinasi warna tersebut dalam kegiatan belajar yang akan dikerjakan pada saat itu.

Guru dan peneliti memberi penjelasan pada anak untuk tidak hanya memperhatikan benda yang menarik tersebut, tetapi juga harus benar-benar mengikuti proses pembelajaran yang baik, sehingga dapat mengenal warna dan membuat bentuk gambar sederhana dengan benar.

Peneliti memberi pengarahan dan penjelasan secara rinci pada anak bagaimana cara membuat gambar dengan menggunakan aplikasi paint dan menghasilkan gambar dengan indah sehingga anak dapat menggambar dengan aplikasi paint dan mewarnai gambar dengan baik dan benar serta dapat melatih imajinasi anak untuk menggambar.

Deskripsi hasil siklus I dijelaskan sebagai berikut: Perencanaan kegiatan yang dilakukan pada siklus I adalah mempersiapkan beberapa hal yang diperlukan dalam pelaksanaan penelitian yaitu membuat RKH, menyusun instrumen aktifitas anak serta membuat media gambar aplikasi paint dengan variasi warna dasar serta contoh hasil teknik menggambar menggunakan aplikasi paint dalam proses pembelajaran.

Siklus I dilaksanakan dalam upaya peningkatan hasil belajar pengembangan visual melalui kegiatan menggambar menggunakan aplikasi paint untuk melatih kemampuan kecerdasan visual anak untuk pembelajaran dibidang seni pada anak RA Al Muhajirin Kota Cimahi dengan 2 kali pertemuan dalam 1 minggu. Kegiatan menggambar menggunakan aplikasi paint dalam pengembangan aspek seni untuk melatih kemampuan kecerdasan visual anak dengan menggunakan media pendukung, 
hal ini sesuai dengan kegiatan harian yang sudah disusun. Langkah-langkah pelaksanaannya sesuai dengan yang dituangkan dalam RKH.

Pelaksanaan pembelajaran pada siklus I dilaksanakan sesuai perencanaan dengan alokasi waktu 3 jam pelajaran. Pelaksanaan tindakan pada siklus I ini diawali dengan memberikan motivasi dengan menggali pengetahuan awal anak serta memberikan informasi kompetensi yang akan dipelajari. Selanjutnya guru membagi anak menjadi 3 kelompok, kemudian guru memberikan tugas kepada masing-masing kelompok tersebut untuk dieksplorasi. Pada tahap berikutnya guru mengamati aktifitas anak dan membimbing kegiatan tersebut serta memberikan kesempatan pada setiap kelompok untuk memperlihatkan hasil kerja dalam kelompoknya. Anak diharapkan dapat menunjukkan dan menceritakan bentuk gambar yang dibuat.

Kegiatan menggambar menggunakan aplikasi paint yang digunakan pada siklus I ini untuk menentukan jenis warna dan bentuk gambar serta kemampuan anak dalam mengkombinasikan masing-masing warna ke dalam bentuk gambar sederhana. Tahap berikutnya, guru memberikan klarifikasi dan penguatan terhadap materi yang telah dikerjakan serta memberikan bimbingan pada anak yang belum memahami materi yang telah dipelajari.

Pada akhir pembelajaran, guru memberikan tugas pada anak untuk menulis kembali kata-kata yang sudah diajarkan. Kegiatan ini dilakukan pada 2 kali pertemuan. Pada akhir pembelajaran diberikan evaluasi. Dari analisis terhadap hasil belajar yang dicapai oleh anak diperoleh data bahwa anak memperoleh nilai Belum Berkembang (BB) 1 orang anak, Mulai Berkembang (MB) 7 orang anak, berjumlah 22 orang anak dari keseluruhan jumlah anak 30 orang, maka jumlah anak yang mendapatkan nilai BSH 6 orang anak, dan BSB 16 orang anak sebesar 75 $\%$, jumlah yang belum memperoleh nilai BSH dan BSB adalah 6 orang dengan persentase sebesar $25 \%$.

Observasi yang dilakukan pada siklus I ini antara lain adalah aktifitas anak saat pembelajaran berlangsung dan pelaksanaan pembelajaran yang dilakukan oleh guru. Hasil observasi guru terhadap aktifitas anak pada saat pembelajaran berlangsung dengan menggunakan lembar observasi aktifitas anak, yaitu persentase aktifitas sebesar $80,0 \%$. Hal ini menunjukkan bahwa aktifitas anak tergolong cukup dari yang diharapkan oleh peneliti. Berdasarkan hasil observasi pada siklus I yang diperoleh tentang aplikasi paint untuk melatih kemampuan motorik halus anak diatas memperlihatkan bahwa rata-rata nilai BSB yang diperoleh adalah 57,2\%, BSH dengan nilai ratarata $21,4 \%, \mathrm{MB}$ nilai rata-rata $17,8 \%$ dan nilai rata- rata $\mathrm{BB} 3,6 \%$.

Dengan demikian, dapat disimpulkan sebagian besar anak di RA Al Muhajirin sudah bisa memahami pembelajaran yang disampaikan guru dalam aplikasi paint untuk melatih kemampuan motorik halus anak dalam artian adanya ketercapaian indikator dalam proses pembelajaran. Berdasarkan hasil dari rekapitulasi siklus I jelas sudah terlihat bahwa terjadi peningkatan terhadap tiap-tiap kegiatan pembelajaran.

Setelah siklus I selesai, dilakukan penilaian terhadap hasil belajar anak, aktifitas anak dalam melaksanakan pembelajaran. Guru dan peneliti secara kolaborasi membuat pertemuan untuk membahas tentang tindakan yang harus diperbaiki serta tindakan yang harus dipertahankan pada pembelajaran. Tindakan tersebut sebagai berikut: 1) Menyampaikan tujuan pembelajaran yang dapat dilakukan dengan lebih jelas pada anak. 2) Memotivasi anak yang tidak aktif dalam kelompoknya, membimbing anak dalam tugas kelompok dengan cara mendekati tempat duduk anak untuk melihat aktifitas anak lebih dekat serta membimbing anak dalam kegiatan tugas kelas. 3) Pengelolaan waktu lebih efektif. 4) Membuat perbedaan antara warna dan bentuk gambar dengan warna dan bentuk gambar lainnya, karena anak kesulitan dalam membedakan kedua hal tersebut, salah satu caranya dengan memberikan perbedaan dan penempatan warna dari masing-masing bentuk gambar yang dihasilkan anak melalui penerapan kegiatan menggambar menggunakan aplikasi paint.

Dari hasil observasi terhadap aktifitas anak, terjadi peningkatan $75,00 \%$ pada siklus I. Hasil persentase aktifitas anak ini disebabkan adanya aktifitas anak pada kegiatan tugas kelompok dan tugas kelas. Selain itu, tindakan guru dengan terus membimbing anak pada kegiatan kelompok juga ikut mempengaruhi kenaikan aktifitas tersebut. Dari data yang diperoleh masih ada anak yang tidak aktif dan telah dilakukan tindak lanjut dengan memberikan pertanyaan dan memberikan sanksi berupa tugas menyelesaikan bentuk gambar dengan teknik menggambar menggunakan aplikasi paint dengan variasi 
warna berdasarkan imajinasi anak yang harus dilakukan didepan komputer tanpa bantuan dari teman kelompoknya.

Berdasarkan hasil yang diperoleh dari pelaksanaan siklus I, maka dapat dikatakan bahwa terjadi peningkatan hasil belajar anak pada pembelajaran dengan menggunakan aplikasi paint. Hal ini dapat kita lihat dari hasil belajar anak. Aktifitas anak pada saat pembelajaran berlangsung dan kemampuan guru dalam melaksanakan pembelajaran. Setelah dilakukan analisis, peningkatan ini berkaitan langsung dengan penggunaan aplikasi paint dan variasi warna serta penggunaan alam sekitar sebagai media pembelajaran.

Aspek yang terpenting adalah melatih kemampuan kecerdasan visual anak serta peningkatan hasil belajar anak. Selain dapat melatih kemampuan kecerdasan visual anak, aplikasi paint dengan variasi warna serta alam sekitar sebagai media pembelajaran dapat juga berfungsi meningkatkan kemampuan seni daya pikir anak pada pengenalan aplikasi paint dan menggambar menggunakan aplikasi paint yang selama ini dianggap sebagai materi yang sulit.

Hasil belajar anak yang diperoleh pada siklus I sesuai dengan harapan yang diinginkan yaitu 75,00\%. Hasil belajar siklus I 75,00\% anak tuntas dan sebanyak 22 orang anak yang memperoleh nilai BSH sebanyak 8 orang anak, dan BSB sebanyak 16 orang anak. Observasi yang dilakukan terhadap aktifitas anak pada siklus I sebanyak $80,0 \%$ anak aktif dalam kegiatan pembelajaran.

Berdasarkan dari seluruh hasil tindakan menunjukkan terjadinya peningkatan hasil belajar anak, peningkatan kemampuan motorik halus anak serta peningkatan terhadap kemampuan guru dalam melaksanakan pembelajaran, maka dapat disimpulkan bahwa penggunaan aplikasi paint dan menggambar sebagai media pembelajaran dapat digunakan pada pembelajaran menggunakan teknik menggambar menggunakan aplikasi paint pada komputer.

\section{SIMPULAN}

Berdasarkan hasil penelitian, dapat disimpulkan bahwa penggunaan aplikasi paint pada komputer dalam melatih kemampuan kecerdasan visual sebagai media pembelajaran yang dapat melatih kemampuan kecerdasan visual anak pada pengembangan kecerdasan visual di RA Al Muhajirin Kota Cimahi, serta dapat meningkatkan kreatifitas anak dalam menggambar menggunakan media aplikasi paint pada komputer. Penggunaan aplikasi paint sebagai media pembelajaran dapat melatih kemampuan kecerdasan visual anak pada pengembangan kemampuan kecerdasan visual anak. Hasil yang diperoleh menunjukkan bahwa terjadi perubahan pada kemampuan kecerdasan visual anak setelah proses pembelajaran dengan menggunakan media aplikasi paint pada komputer.

\section{UCAPAN TERIMA KASIH}

Ketua peneliti beserta anggota mengucapkan terimakasih banyak kepada Tim dan RA Al Muhajirin Kota Cimahi atas kerjasama yang baik selama penelitian ini dilakukan. Kepercayaan lembaga yang diberikan akan terus kami jaga dan akan kami kembangkan terus pada penelitian-penelitian yang akan datang.

\section{DAFTAR PUSTAKA}

Joni (2015). Hubungan Pola Asuh Orang Tua terhadap Perkembangan Bahasa Anak Prasekolah (3-5 tahun) di PAUD AlHasanah Tahun 2014. Journal Obsesi (Journal of Early Chilhood Education, $1(1), 42-48$.

Lina, A. (2016) Stimulasi Kecerdasan Visual Spasial dan Kecerdasan Kinestetik Anak Usia Dini Melalui Metode Kindergarten Watching Siaga Bencana Gempa Bumi di PAUD Terpadu Permata Hati Banda Aceh. jurnal visipena vol. 6 no. 2 hal 2639

Mulyasa, E. (2009). Praktik Penelitian Tindakan Kelas. Bandung: Prenada Media.

Musfiroh, T. (2005). Bermain Sambil Belajar dan Mengasah Kecerdasan. Jakarta: PT Indeks.

Nik Amah, N. E. S. (2017). Permainan Poli Dana untuk Menumbuhkan Kecerdasan Finansial pada Anak Usia Dini. Jurnal CARE, 4(2), 31-40.

Pebriana, P., H. (2017). Analisis Penggunaan Gadget terhadap Kemampuan Interaksi Sosial Anak Usia Dini. Journal Obsesi (Journal of Early Chilhood Education, 1(1), $1-11$.

Ramli. (2005). Pendampingan Perkembangan Anak Usia Dini. Jakarta: Depdiknas.

Sujiono, Nurani, \& Yuliani. (2009). Konsep Dasar Pendidikan Anak Usia Dini. Jakarta: Universitas Terbuka.

Undang-undang Sisdiknas. (2003). Pendidikan Anak Usia Dini. Jakarta: Depdiknas. 